\title{
Coaching Competency as a Solution for Indonesian Headmaster of Elementary School in Disruption Era
}

\author{
Zahara Tussoleha Rony ${ }^{1}$, Sani Aryanto ${ }^{2}$ \\ \{zahara.tussoleha@dsn.ubharajaya.ac.id ${ }^{1}$, sani.aryanto@dsn.ubharajaya.ac.id ${ }^{2}$ \} \\ Universitas Bhayangkara Jakarta Raya ${ }^{1,2}$
}

\begin{abstract}
The disruption era is an indicator of technological growth received in various fields including education. Headmaster as a leader is required to be able to set a leadership pattern that could provide accelerated assistance in fostering teachers in Elementary Schools with most of the millennial teachers. Coaching competency is one of the competencies expected to anticipate imbalance communication system between headmaster and teacher. This study used a qualitative study method. According to the results of this research concluded that coaching competency had to be explicitly had by headmaster beside competency of managerial, entrepreneurial, supervision, personality, and social. This is because coaching competency has such various, complex, and not an easy activity. Therefore, the results of this study are expected to be the solution for headmaster in facing.
\end{abstract}

Keyword: Coaching Competency, Disruption Era, Gen-Y, Headmaster

\section{Introduction}

In this Disruption Era, the literature has shifted from the national to the regional dimension. Regions can evolve into regional innovation systems if applied research is integrated into the regional industry and if localized learning processes are fed with information, the interaction between agents and appropriate investments in research and education [1]. The disruption era is a period of compilation that occurs unexpectedly, fundamentally and almost all aspects of life. Today's world is in a phenomenon where world movement is no longer linear. New records, present transfer the old order that is not in accordance with the times. Disruption era initiated the birth of a new, more innovative and massive interaction model. The scope of change is very broad, from the business world, banking, transportation, social affairs, to education. Because this era gave birth to two important choices: change or become extinct. No doubt, disruption will encourage digitalization of the education system.

Education is required to be able to balance the civilization of society. The disruption era has pushed us to think fast and target oriented, from the beginning using manual systems turned into digital systems, so this condition requires every element of education to revitalize the education system in schools as technical units of education service providers. Moreover, in the current era of disruption, the growth of millennial teachers is increasing.

Millennial are the largest workforce in Indonesia. Based on BPS data in 2018, of the total workforce in Indonesia which reached 160 million, almost 56\% of them were classified as 
millennial which amounted to 90 million [2]. They will be the leaders and movers of Indonesian development in the demographic bonus at 2020-2030, therefore Primary Schools as the smallest unit of formal education in Indonesia need to make a lot of investment in developing teachers as an effort to build superior human resources to encourage innovation [3].

The Headmaster is the highest position in the school and has a very central role in modifying the education system in elementary school. According to Permendiknas RI No. 13 Tahun 2007 about the Headmaster Standards that the 5 competencies that must be possessed by Headmaster in elementary school include: personality competency, managerial competence, entrepreneurial competence, social competence, and supervision competence. Theoretically, these five competencies are considered representative and become the headmaster capital in providing education services today. In the process of mastering these five competencies it is not easy, especially in the disruption era and changes lifestyle, social, communication, culture, become a direct challenge faced by the headmaster.

According to Brosdahl and Carpenter's there are several generations of generations seen from the vulnerable, including Silent Generation (1925-1945), Baby Boomers (1946-1960) Generation X (1961-1981), Generation Y (born after 1981) [4]. Most principals belong to the Generation X group, while the teachers are mostly classified as Generation Y, and students are in the Generation $\mathrm{Z}$ order. Because the challenges in the disruption era are not easy to deal with especially when principals do not have the seriousness in increasing various competencies, especially competencies directly increasing the motivation of teachers to continue to encourage their performance in improving the quality of education, because the competency of principals influences the effectiveness of teachers in teaching including in the development of schools to be much better [5].

Competence that is important in motivating and encouraging teacher performance is coaching competency. The latest research that is relevant to the effectiveness of coaching is done by Majid and Sugito who prove that these competencies can improve individual performance that has an impact on organizational progress [4]. Coaching is an effort to help individuals or organizations achieve optimal performance, overcome obstacles to growth, and to achieve specific goals and challenges as a means of fulfillment, personal and professional development [6]. This competency is one of the sub-competencies of supervision. Supervision is an effort to provide services and assistance to improve the quality of teaching teachers in the classroom and develop teacher quality potential [7]. Implicitly in the competence of supervision, there is a competency that is very important and sometimes does not appear and even neglected by most principals, these competencies are coaching competency.

Conceptually, coaching is seen as a simple theory and is not explicitly raised. But in fact, this theory is a series of stages that are very complex and need to be explicitly owned by the headmaster. Therefore, researchers conducted in-depth studies related to the importance of headmaster in elementary school having coaching competency in the era of disruption because to be an effective leader, you must be an effective coach.

The question that arises, is the headmaster ready to make themselves as inspirations for teachers dominated by millennial generation? In order for this question to be answered, at least accurate data is needed about the readiness of Elementary School in the face of the disruption era. But unfortunately the condition of elementary education in Indonesia is quite alarming, as evidenced by the Global Competitiveness Index 2017-2018 of 137 countries, Indonesia is ranked $36^{\text {th }}$ and the factor that makes Indonesia's condition in the eyes of the world still weak is the condition of elementary education [8]. 


\section{Methodology}

This study used a qualitative approach with a type of narrative. The research procedure was preceded by the results of previous studies that were relevant to the phenomenon of coaching competence as a solution for headmaster in an elementary school in the face of disruption era. Then a deepening of the study was carried out from the theories of disruption era, Gen-Y, coaching competency, and headmaster. The results of the data are sorted into themes and followed by an inventory of literature in accordance with the study in this research. To get indepth results, triangulation was done by focusing on group discussions with headmaster and teachers and coaching experts. The following stages of this research can be seen in Fig. 1.

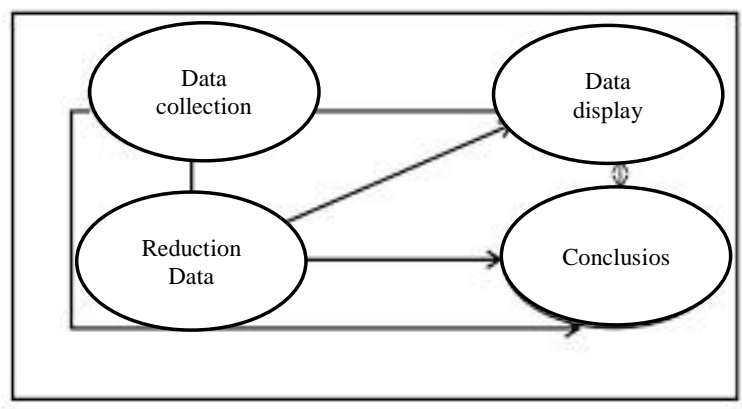

Fig. 1. Stages of Qualitative Research

The procedure of this research includes four stages including (1) collecting relevant data in accordance with the research variables (2) the researcher presents the collected data (3) the reduction and inventory of data (4) concludes based on the results of valid and reliable data verification [9]

\section{Result and Discussion}

\subsection{Elementary Education in Disruption Era}

Industry 4.0 encompasses a variety of technologies, principles, and methods, to make production systems more autonomous, dynamic, flexible and accurate [10]. The era of Industry 4.0 was marked by rapid innovation and technology. As one of the important elements in life, the education sector must take a big role in the arena of global competition. The readiness of human resources and education is a very important formation space in the face of disruption era. The digital transformation sweeping through the advanced economies is labeled Industry 4.0 and it is profoundly modifying the current business and education models. Industry 4.0, also called integrated industry and internet, stands for the fourth industrial revolution [11]. The disruption era initiated the birth of a new business model with a more innovative and disruptive strategy. The scope of change is very broad, ranging from the world of business, banking, transportation, social society, especially in the education sector. This era requires humans to change or become extinct. Undoubtedly, disruption will encourage digitalization to mark the beginning of the democratization of knowledge that creates opportunities to productively exploit the world of technology. The challenge for education personnel in the disruption era is how to create human resources that are able to survive and develop in an era of all innovative and 
creative. The challenge is to prepare human resources that have the power of innovation and creativity. In the disruption era, headmaster and teacher are no longer the only source of knowledge, but rather act as inspiration. For this reason, principals and teachers must be able to make themselves the bridge of knowledge for students.

\subsection{Generation $Y$}

Another challenge facing the education sector of disruption era is the growth of the teacher millennial generation or the Gen-Y the teacher in elementary school. Many of the terms Gen-Y proposed by experts include Net-Gen, Google Generation, Digital Natives, and Millennial [12][14]. We define Generation Y (broadly) as all people born between 1982 \& 2000 [15], [16]. Millennial have grown up in the digital age. They show greater familiarity than previous generations with communication, media, and digital technologies. Because they are more "wired," this gives Millennial a competitive advantage and makes them an asset when it comes to working with new technologies. However, also points out that, "they are also sometimes called the "Trophy Generation" or "Trophy Kids" based on the emerging trend in sports and competition to reward everyone for participation, rather than for winning. Because of this experience, they have been said to reject in-house competition and politics [17].

Millennial are thought to be skeptical of long-term commitments and are said to desire greater flexibility in their career. Members of this generation are described as preferring collective action, working in teams, wanting work that really matters to them, and being civicminded, eco-aware, confident, conventional, optimistic, and socially conscious [18]. One research study described millennial as "opinionated" and they "[expect] to be heard" [19]. The characteristics of the millennial generation that are most visible are the desire for challenges and high ambition. They are used to working hard, but they are easily bored and always want to get a new atmosphere [20].

Description of the Gen-Y characteristics is a challenge for the headmaster to have appropriate motivations and competencies, especially the role of headmaster in elementary school becomes strategic, as one of the determinants of the success of millennial teachers in providing education services in the disruption era. Leadership of headmaster plays a role in forming a conducive environment for teachers in carrying out their duties [21].

The headmaster has a very central role in modifying the education system in elementary schools including providing good direction and examples for teachers and students, moreover, the role of teachers today is not just the transfer of knowledge, but must strive to cultivate appropriate values with student characteristics in the current era. The headmaster is expected to be able to make a new breakthrough in developing schools that are innovative, futuristic and comfortable. Therefore headmaster must have special competencies that can make an accelerative effort in responding to challenges in disruption era.

\subsection{Headmaster Competency}

Elementary School is an institution that is complex and unique. The development of an elementary school is greatly influenced by the leadership of the headmaster. Leadership is the ability to inspire and support people who need to achieve organizational goals [22]. Leadership is the ability to direct a group towards achieving goals, including how principals provide direction to their teachers [23]. With the birth of the millennial generation, leaders must pay attention to leadership style and behavior within the organization to achieve organizational success [24]. Leadership style and behavior refers to the activities of leaders, including the 
characteristics and effectiveness approaches. Moreover, sometimes the nature of a person tends to be able to help understand a leader.

The headmaster as a leader can ideally find the right leadership style for the genes. Understand the style of communication Gen-Y. As the name implies, there is a mention of the Gen-Y, because this generation always asks their reasons for doing something "Why?" So when communicating with Gen-Y, leaders must convey information clearly, transparently and honestly [19].

In the context of education in Indonesia, the headmaster has two main roles, namely as formal officials and managers. As formal officials, the headmaster is appointed through applicable processes, procedures, and regulations. As a manager, the headmaster is a planner, organizer, and controller. In this case, the headmaster must pay attention to three things, namely the process; utilization of all organizational resources; and achievement of set organizational goals. As a leader, the headmaster must encourage a strong will with the enthusiasm and confidence of the teachers, staff, and students in carrying out their respective duties. [25], so that the urgency of the headmaster role is the component of education that plays a role in improving the quality of education [26].

Changes in the educational order in the era of disruption must be answered with innovative and creative by the headmaster. Therefore, headmaster must have competent competencies in carrying out their roles as leaders, formal officials, and managers. At least there are 8 competencies that must be possessed by the headmaster to carry out their duties well, including: (1) Have a great sense of responsibility for the implementation of all activities that support the achievement of school goals or education goals. (2) Have the ability to motivate people to carry out their duties responsibly and sincerely. (3) Have self-confidence, exemplary and authority. (4) Can establish a harmonious relationship with the community and can involve them actively in order to realize school goals. (5) Able to guide, supervise and foster subordinates (teachers) so that each teacher obtains assignments that are in accordance with his expertise; (6) have curiosity and have a mindset oriented far ahead. (7) Brave and able to overcome difficulties; (8) Always innovating in everything [27].

According to Permendiknas RI No. 13 Tahun 2007 about the Headmaster Standards that at least 5 competencies must be possessed by the headmaster including personality competence, managerial competence, entrepreneurial competence, social competence, and supervision competence [28]. The five competencies are the headmaster of the school in providing educational services now and are considered representative, but in the face of the disruption era, there needs to be a priority scale of the five competencies that exist. Supervision competence is considered as a priority scale that must be developed by the headmaster in the current disruption era. Supervision is the ability of the principal in fostering the teacher to develop his professionalism [29]. Coaching carried out by the headmaster is to develop better and quality teaching and learning situations, especially for teachers, so in self-development, some guidance techniques are needed so that coaches can carry out specific tasks [30]. Supervision carried out by headmaster effectively and sustainably is expected to contribute significantly to teachers in their efforts to improve their working [31]. Implicitly, coaching competency is included in the part of supervision competency, but unfortunately, this competence has not been implemented optimally by the most headmaster, so there is a need for preventive efforts in pursuing coaching competencies to appear explicitly.

\subsection{Coaching Competency as a Solution in Disruption Era}

Coaching is the competency of the headmaster to motivate and bring up the commitment of teachers to make changes to targets in increasing work productivity. Theoretically coaching 
is identified as a formal and informal meeting process carried out by the leader to his subordinates to provide constructive training in dealing with the work environment and help subordinates in anticipating obstacles in order to achieve optimal performance [32]. Parsloe and Wray stated that coaching is a process of helping someone to learn and develop in improving performance [7]. Furthermore, coaching is one of the strategies for developing school capacity in an effort to improve the performance of individuals, organizations and the school system [7].

In coaching activities, a headmaster as a coach will help the teacher or coachee in finding the strength of their self. The coach will try to empower coachee and he will try to explore as much as possible the potential of coachee through "powerful questions" and finally coachee will find their own potential [33]. The capacity of headmaster also considered being a facilitator who develops the ability of teachers in elementary school and required to find the solutions. The headmaster is responsible for keeping the conversation focused on clearly defined goals while facilitating teacher thinking, assessing progress, and providing constructive feedback. Therefore, the headmaster as a coach has the responsibility to generate ideas and choices, take action to achieve goals and report on progress [32].

Coaching is different from older management 'command and control' approach, There are five skills that the principal must do as a coach, including:

a. Building trust to open a better initial relationship with the teacher as a coachee, so the teacher is expected to feel comfortable when implementing coaching; a coach cannot help the success of coachee if he does not recognize well and responsive to the needs of his members. Principals can ideally be sensitive to personality and social style and coachee personality. They can communicate and relate well. Generation Y has a sincere character, they do not like politics. Therefore as coaches, they need to create relationships that begin with a sincere goal and intention to facilitate coachee to improve their performance. In other words, when agreeing to coach, the headmaster has qualified personal competencies in directing teachers to enhance the spirit of professionalism. Coaching activities are also a collaborative effort and not an effort to control staff work.

b. Active listening, it means that the headmaster as a coach must really pay attention to things that are delivered by the teacher/coachee. As a headmaster in this activity, he trained to talk a little, listen a lot. Effective listening means that the coach understands the things delivered by Coachee. Coach writes and documents well and in detail all the messages delivered by coachee. Written records can be a guide and further plan. This record will be submitted again by the coach.

c. Calibrating is an activity in reflecting back on the words conveyed by the teacher/coachee, so they really feel better to hear by the headmaster or coach; When the headmaster can repeat the things conveyed by the teacher, this becomes an appreciation and creates motivation for the coachee that he is listened to and cared for well. And this process describes the building significant empathy and trust in delegating large responsibilities

d. Asking the right question is the most fundamental activity in coaching. This activity is an effort to explore the teacher's ideas to create or achieve something expected of the school in the face of disruption era. The questions submitted must be precise in order to produce a direction that moves teacher/coachee in getting a new idea or solution in a particular area to create a commitment. Therefore, this activity requires the headmaster or coach to be more skilled in making effective questions, arouse awareness of things, create a sense of responsibility, encourage discovery and investigation, produce clarity, challenge assumptions, birth to commitment, change perspectives, move the teacher or coachee to take action 
e. Open and closed questions. Open questions inspire the teacher / coachee to give an answer to further and deeper thinking about something. Open questions can bring coach and coachee to be able to uncover depth and move towards effective conversations, while closed questions can be answered yes or no. In this process a headmaster is trained in giving fewer orders, asking more questions.

f. Giving Feedback is about giving information in a way that encourages the recipient to accept it, reflect on it, learn from it, and hopefully make changes for the better. Being able to give feedback is a skill that is useful in our personal and professional lives [34]. The impact of good feedback is successfully arousing coachee/ evaluating his own performance. In this activity, the headmaster can evaluate the actions carried out by coachee, examples of evaluating the completion of a report. And how coachee feels after completing the report [32].

At this stage, the headmaster gives specific feedback rather than making an assessment. Giving feedback of the headmaster needs to use positive sentences accompanied by enthusiasm and pride in the achievements achieved by coachee. there are 4 types of feedback styles, namely active responses - constructive, responses that are accompanied by positive comments (praise) both verbal and non-verbal (tone, voice, posture, gesture, face, breathing pattern) indicate sincere interest and enthusiasm in relation with the success that is being described.

Passive - constructive responses, responses accompanied by positive comments with low energy in supporting non-verbal. Active - destructive responses, responses accompanied by negative comments (sometimes wrapped in positive things) and negative non-verbal behaviors such as frowning or complaints. Passive - destructive responses, responses that are not accompanied by involvement and are more visible as verbal and non-verbal inconsistencies.

To get more effective results, the headmaster and teacher must agree on the rules of the game beginning with determining the purpose of the meeting, how many meetings and the duration of each meeting. The following are the conditions that must be done by headmaster when coaching can be seen in Table 1 .

Table 1. Terms of Coaching Competency

\begin{tabular}{ll}
\hline & Terms of Coaching Competency \\
& \\
$1^{\text {st }}$ Duration of & $1^{\text {st }}$ Relationship generally has a set duration typically from $6-$ \\
Relationship & 18 months. \\
$2^{\text {nd }}$ Structure & $2^{\text {nd }}$ Generally structured and more regular \\
$3^{\text {rd }}$ Focus & $3^{\text {rd }}$ Short-term focus on specific development areas/issues. \\
$4^{\text {th }}$ Use of diagnostic & $4^{\text {th }}$ Profiling tools (e.g. 360 degree feedback, personality \\
tools & questionnaire) are commonly used to offer alternative insights \\
$5^{\text {th }}$ Role** & $5.1^{\text {st }}$ Provide individuals and teams with opportunities for \\
& gaining new skills, and personal development. \\
& $5.2^{\text {nd }}$ Offer learning opportunities geared to individual needs. \\
& $5.3^{\text {rd }}$ Encourage a positive attitude to Learning. \\
& $5.4^{\text {th }}$ Provide flexibility in the learning process. \\
& $5.5^{\text {th }}$ Allow protégés to select what and how they learn. \\
\hline
\end{tabular}




\title{
4 Conclusion
}

\author{
* Source: Brefi Group Limited and Topic Gateway Series
}

Coaching competency is considered as the solution for headmaster in elementary schools in anticipating changes that occur in an era of disruption with five skills that must be mastered, including trust building, active listening, calibrating, asking questions, giving feedback. The five skills are expected to be able to encourage the commitment of millennial teachers to improve their work ethic and encourage the creation of solutions, creative, and innovative ideas teachers in facing educational conditions in disruption era through effective and efficient communication skills between headmaster as coaches and teachers as the coachee.

\section{Acknowledgments}

Thank you to all those who helped write this article, especially the academic community at the Faculty of Education, Universitas Bhayangkara Jakarta Raya.

\section{References}

[1] A. Ciffolilli and A. Muscio, "Industry 4.0: national and regional comparative advantages in key enabling technologies," European Planning Studies, 2018.

[2] BPS, “Tingkat Pengangguran Terbuka (TPT)," Bps, 2016.

[3] G. Oster, "Emergent Innovation: A New Strategic Paradigm," J. Strateg. Leadersh., 2009.

[4] R. N. Bolton et al., "Understanding Generation Y and their use of social media: A review and research agenda," J. Serv. Manag., 2013.

[5] J. Bungai, "Pengaruh Kompetensi Kepala Sekolah, Iklim Sekolah, dan Keefektifan Mengajar Terhadap Prestasi Lulusan SMA,” J. Ilmu Pendidik., vol. 13, no. 2, 2016.

[6] C. Wilson, Best practice in performance coaching: A handbook for leaders, coaches, HR professionals and organizations. Kogan Page Publishers, 2007.

[7] S. Suryantini, "Peningkatan Kompetensi Supervisi Kepala Sekolah Melalui Supervisi Kelompok Di Sekolah Dasar,” Manaj. Pendidik., vol. 11, no. 1, pp. 8-16, 2016.

[8] K. Schwab, “The Global Competitiveness Report 2018," 2018.

[9] J. Creswell, Research Design : Pendekatan Kualitatif, Kuantitatif, dan MIxed. 2014.

[10] V. L. da Silva, J. L. Kovaleski, and R. N. Pagani, "Technology transfer in the supply chain oriented to industry 4.0: a literature review," Technology Analysis and Strategic Management, 2018.

[11] M. Götz and B. Jankowska, "Clusters and Industry 4.0-do they fit together?," Eur. Plan. Stud., 2017.

[12] J. B. Balda and F. Mora, "Adapting leadership theory and practice for the networked, millennial generation,” J. Leadersh. Stud., 2011.

[13] B. Evans, "The millennial generation is productive in the workplace," Millenn. Gener., pp. 56-65, 2011.

[14] Tracey L. Cekada, "Training a multigeneration workgorce: Understanding key needs \& learning sytles," Prof. Saf., 2012.

[15] W. Strauss and N. Howe, "Generations: The History of America's Future 1584 to 2069 
(Book).," Futurist, 1991.

[16] T. F. Cahill and M. Sedrak, "Leading a multigenerational workforce: strategies for attracting and retaining millennials.," Front. Health Serv. Manage., 2012.

[17] A. Tolbize, "Generational differences in the workplace," Res. Train. Cent. community living, vol. 5, no. 2, pp. 1-21, 2008.

[18] S. A. Hewlett, L. Sherbin, and K. Sumberg, "How Gen Y \& Boomers Will Reshape Your Agenda," Harvard Business Review. 2009.

[19] J. L. Hartman and J. McCambridge, "Optimizing millennials' communication styles," Bus. Commun. Q., 2011.

[20] J. Kristensen, "Recruiting and Retaining Generation Y. Msc," Int. Bus. Econ. Aalborg Univ., 2008.

[21] I. M. Warga, N. Dantes, and N. Natajaya, "Determinasi Sikap Profesi, Kompetensi Mengelola Proses Pembelajaran dan Kepemimpinan Kepala Sekolah terhadap Kepuasan Kerja Guru Sekolah Dasar di Kecamatan Melaya, Kabupaten Jembrana," PENDASI J. Pendidik. Dasar Indones., vol. 3, no. 1, 2013.

[22] A. J. DuBrin, Impression management in the workplace: Research, theory, and practice. 2011.

[23] B. M. Bass and R. E. Riggio, "Transformational leadership (2nd ed.).," Transformational leadership (2nd ed.). 2006.

[24] S. M. Jex and T. W. Britt, "Organizational psychology: A scientist-practitioner approach (3rd ed.).," Organizational psychology: A scientist-practitioner approach (3rd ed.). 2014.

[25] A. Afroni, "Kompetensi Kepala Sekolah Sebagai Supervisor Pembelajaran Dalam Upaya Peningkatan Kompetensi Guru,” Edukasia Islam., vol. 7, no. 1, 2009.

[26] A. Warman, "Hubungan Supervisi oleh Kepala Sekolah dan Kompetensi Guru Dengan Kepuasan Kerja di Sekolah Dasar Negeri Se-Kecamatan Baso Kabupaten Agam,” alfikrah J. Manaj. Pendidik., vol. 2, no. 1, pp. 29-38, 2016.

[27] A. Wahyudi, "Pengaruh Disiplin Kerja, Motivasi Kerja, dan Supervisi Kepala Sekolah Terhadap Kinerja Guru," Econ. Educ. Anal. J., 2012.

[28] V. A. Sudharta, I. Bafadal, and S. Sultoni, "Kepribadian yang Baik untuk Keefektifan Kepemimpinan Kepala Sekolah,” JAMP J. Adm. dan Manaj. Pendidik., vol. 1, no. 4, pp. 440-447, 2018.

[29] M. Simbolon, "Penerapan Pendekatan Supervisi Kolaboratif untuk Meningkatkan Kompetensi Profesional Guru di SD Negeri 10 Lumban Suhisuhi Kecamatan Pangururan Kabupaten Samosir," Maj. Ilm. INTI (Informasi dan Teknol. Ilmiah), vol. 13, no. 3, pp. 350-356, 2018.

[30] S. Sinaga, "Upaya Pembinaan Kepala Sekolah dalam Meningkatkan Profesionalitas Guru di Sekolah Dasar Negeri (SDN) Se-Kecamatan Pangururan Kabupaten Samosir," Maj. Ilm. INTI (Informasi dan Teknol. Ilmiah), vol. 13, no. 3, pp. 381-398, 2018.

[31] A. Taufiq, "Model Supervisi yang Membelajarkan Bagi Konselor Sekolah dan Profesi Sejenis," PEDAGOGIA, vol. 15, no. 3, pp. 742-750, 2018.

[32] R. H. Wiwoho, The Practical Business Coach. IndoCoach, 2005.

[33] O. Y. A. Wijaya and W. E. D. Radianto, "Mentoring dan Coaching sebagai Strategi Pengembangan Pendidikan Kewirausahaan: Studi Fenomenologi," J. Apl. Manaj., vol. 14, no. 4, pp. 675-682, 2016.

[34] D. Lynch, "Improving teaching through coaching, mentoring and feedback: a review of literature," MIER J. Educ. Stud. Trends Pract., vol. 4, no. 2, 2016. 